\title{
The Effect of Breadfruit Leaf Extract (Artocarpus Altilis $P$ ) on Spatial Memory of In Male Strain Mice Which Indicated By Alcohol
}

\section{B A Kadir ${ }^{1}$, E R Kasimo², T Ilmi $^{1}$}

${ }^{1}$ Pharmacy program, Faculty of helath Sciences, Kadiri University ${ }^{2}$ Medical Lobolatory Technology, Faculty of Health Sciences, Kadiri University

Email:

mujtahid@unik-kediri.ac.id

Received : November 5, 2020

Accepted : November 11, 2020

Published : November 30, 2020

\begin{abstract}
Background: Spatial memory is working memory that is used to recall when performing certain tasks which is a combination of attention, concentration, and short-term memory. Breadfruit leaves contain compounds flavonoids, tannins, saponins that are as antioxidants that can prevent cognitive disease. Purpose: This study was to determine the effect of breadfruit leaf extract on spatial memory in 10\% alcohol-induced mice using the Y-Maze Methods: Method: This study used 25 mice which were divided into 5 groups, namely the Biloba Gingko positive group, the NaCMC Negative Group and the treatment group consisted of doses of 1 10, 15, $20 \mathrm{mg} / 20$ grams BB of Mice. Every 10\% alcoholinduced mice were then tested by inducing preparations according to the treatment group. The results of the time calculation on Y maze are statistically analyzed with one-way ANOVA Results: From the results of the $y$ maze test it is known that gingko biloba gives the best effect then the treatment group with a dose of $20 \mathrm{mg}$, the group $15 \mathrm{mg}$ and $10 \mathrm{mg}$, and the negative group giving $\mathrm{Na}$ CMC. Conclusion: The results of this study concluded that the breadfruit leaf extract (Artocarpus altilis P) can improve the spatial memory of alcohol-induced mice $10 \%$.
\end{abstract}

Keywords: $Y$ - Maze, spatial memory, breadfruit, alcohol

Copyright (C) 2020 IIK STRADA Indonesia All right reserved.

This is an open-acces article distributed under the terms of the Creative Commons Attribution-ShareAlike 4.0 International License.

\section{INTRODUCTION}

Decreased cognitive function or known as dementia is caused by aging, alcohol consumption, heredity and an unhealthy lifestyle (Riasari et al, 2015). The Research and Development Agency for Health of the Ministry of Indonesia shows that in 2018 the proportion of alcoholic beverages in people aged $\geq 10$ years has increased from 2017 (Ministry of Health, 2018). Alcohol through action, becomes acetyldehyde which will cause ordering reactive which can cause cell damage in the hippocampus (Hernández JA et all, 2016).

Excessive alcohol consumption is one of the triggers for chain reactions through the oxidative stress mechanism. Oxidative stress is a condition in which free radicals in the body are not balanced with the body's antioxidants. Reactive Oxygen Species (ROS) are normally controlled by antioxidants that are formed in the body as a defense against damage caused by ROS. This chain reaction of ROS can cause damage to cell membranes, proteins, DNA, and lipids which can result in cell damage (Feng Y, 2012) 
One of the plants that is often used is breadfruit leaves (Artocarpus altilis P). Breadfruit plants can grow in tropical climates, especially Indonesia. In this study, based on the result of breadfruit leaves contain quercetin, cyclommunol, routine, gallic acid, phenol, tripenoid and flavonoid compounds (Riasari, et al., 2015). Breadfruit leaves are often used to treat various diseases such as hypertension, cholesterol, heart, liver, diabetes and so on, the ability of breadfruit leaves is said to be closely related to the high antioxidant phytochemical content in these plants (Edi, et al., 2009 ).

Antioxidants can stop the process of cell damage by giving electrons to free radicals and we have identified that flavonoid compounds also have the ability to prevent memory loss, which can cross the blood brain barrier in test animals after being given orally in testing (Junvidya, et al., 2019). The objectives of this research are knowing the effect of giving the ethanol extract of breadfruit leaves (Artocarpus altilis P) on the spatial memory of male white mice (Mus musculus) induced by alcohol, using the maceration method with $70 \%$ ethanol solvent with positive control gingko biloba.

\section{METHODS}

This research is an experimental study conducted at the Pharmacy Laboratory of the Faculty of Health Sciences, Kadiri University. The memory test in mice was carried out by using the Morris water maze method using 25 male white mice divided into 5 groups. The tools used in this study were mice oral spoit, glassware (pyrex), mortar, stamper, morris water maze. The materials used in this study were basil herbs, 30 mice, $96 \%$ ethanol, $0.5 \% \mathrm{Na} \mathrm{CMC}$, ethyl acetate, n-hexane, aquadestilata, filter paper.

Basil herb extract (Ocimum sanctum) is made by maceration. The herb powder of basil is weighed as much as 100 grams, then each is placed in a dark (brown) glass bottle. The bottle that has been filled with powder is filled with $70 \%$ ethanol solvent, then left for 3 days in a room that is not exposed to direct sunlight. The resulting macerate is filtered with a flannel cloth to separate the filtrate from the pulp and then it is concentrated.

The chemical identification reactions of basil herbs are as follows:

1. Test the flavonoids by means of 1 gram of extract plus methanol until submerged and then heated. Filtrate added $10 \% \mathrm{NaOH}$ appears red, so it is positive for flavonoids.

2. Test for alkaloids by extracting 2 grams of plant material plus $10 \mathrm{ml}$ of chloroform and a few drops of ammonia. Chloroform fraction by taking the chloroform fraction slowly with a dropper. Chloroform fraction was acidified with $2 \mathrm{M} \mathrm{H} 2 \mathrm{SO} 4$. The $\mathrm{H} 2 \mathrm{SO} 4$ fraction was taken and then added with Meyer, Dragendorf, Wagner reagent. White precipitate with Meyer reaction, redorange precipitate with Dreagendorf reagent and brown precipitate with Wagner's reagent, so there are alkaloids positive (Kusdi et al., 2010).

3. Terpenoid Test A number of extracts were added with $1 \mathrm{ml}$ of anhydrous acetic solution and $1 \mathrm{ml}$ of concentrated sulfuric acid solution. The appearance of green to blue indicates the presence of terpenoids (Harborne, 1987).

4. Tannin Test as much as 0.5 grams of the extract was put into the test tube, then added 2 drops of $1 \%$ iron (III) chloride solution, observe the changes. If there is blackish blue or blackish green, it indicates the presence of tannins (Harbone, 1987).

This study consisted of 5 groups, the positive group using gingko biloba, negative control Na$\mathrm{CMC}$, the test group dose $15 \mathrm{mg} / 20 \mathrm{gr}$ BW for mice, dose $210 \mathrm{mg} / 20 \mathrm{gr} \mathrm{BW}$ for mice and a dose of $320 \mathrm{mg} / 20 \mathrm{gr}$ BW for mice.

In the first stage, the experimental animals after experiencing adjustments to the environment and surrounding conditions were carried out by the Morris water maze test without giving the extract for 5 days. On day 5, calculating the T0 value, then induced with $10 \%$ ethanol to determine the initial condition of the cognitive abilities of mice for 10 days then the Morris water maze test was carried out twice a day and calculated the T1 value for each test animal from each treatment group. The test animals were divided into 5 groups, each group of 5 animals. The treatment was carried out for 10 
days with the Morris water maze test twice a day and calculating the T2 value. The data obtained from the water maze test were then analyzed using one way anova.

\section{RESULTS}

Phytochemical screening uses the color test method with a test tube and uses reagents in accordance with the class of compounds to be tested, alkaloids, flavonoids, terpenoids and tannins. The following are the results of phytochemical screening observation.

Tabel 1. Phytochemical test

\begin{tabular}{|c|c|c|c|c|}
\hline No & Phytochemical test & reactor & Color & Result \\
\hline \multirow{3}{*}{1.} & \multirow{3}{*}{ Alkaloid } & Mayer & $\begin{array}{l}\text { Whait or yellow precipitate brown to } \\
\text { black precipitate }\end{array}$ & + \\
\hline & & Bouchardat & & - \\
\hline & & Dragendorf & The sediment is orange to red brown & + \\
\hline 2. & Flavonoid & $\begin{array}{l}\mathrm{HCl}(\mathrm{P})+\text { Serbuk } \\
\mathrm{Mg}+\text { Amil Alkohol }\end{array}$ & $\begin{array}{l}\text { Orange or red coating on amyl } \\
\text { alcohol }\end{array}$ & + \\
\hline 3. & Tanin & $\mathrm{FeCl}_{3} 1 \%$ & Dark blue or blackish green & + \\
\hline 4. & Terpenoid & $\begin{array}{l}\text { Kloroform + Asam } \\
\text { asetat anhidrat + } \\
\mathrm{H}_{2} \mathrm{SO}_{4}(\mathrm{p})\end{array}$ & Green blue or blackish green color & + \\
\hline
\end{tabular}

The results of this qualitative test prove that the ethanol extract of breadfruit leaves contains alkaloids, flavonoids, tannins and terpenoids. Flavonoids and tannins can provide neuroprotective effects (gothic, 2017) where neuroprotective is a mechanism to reduce damage to the central nervous system caused by strokes and also degenerative diseases by preventing damage to neuron cells. Flavonoids also have a role in improving spatial working memory and tannins are also a class of flavonoids because they have two rings of aromatic atoms that are held together by three carbon atoms (Gothic, 2017).

Pharmacological tests on male white mice (Mus musculus) were carried out to determine the efficacy or ability as a memory enhancer in spatial memory by extracts of breadfruit leaves (Artocarpus altilis P) by giving several tests, such as a 5 -day trial followed by $10 \%$ alcohol induction. for 7 days and after that it was given treatment with control $(+)=$ gingko biloba, control $(-)=\mathrm{Na}$ CMC $0.5 \%$ and with three variations of the dose of breadfruit leaf extract, dose $1=5 \mathrm{mg} / 20$ grams $\mathrm{BW}$ of mice, dose II $=10 \mathrm{mg} / 20 \mathrm{gram}$ BW for mice and dose III $=20 \mathrm{mg} / 20 \mathrm{gram}$ BW for mice.

Morris water maze is a challenging test for mice because it requires a complex thought process, including spatial localization based on visual cues that sequentially involves processing, retrieval, retention and consolidation events to reach hidden platforms (Ina, 2017). Therefore, researchers chosing this method to test memory in test animals. So that from 25 days of treatment on test animals, data can be obtained to strengthen the study of the morris water maze.

Tabel 2. Average escape latency T0, T1, T2

\begin{tabular}{cccccc}
\hline \multirow{2}{*}{ Group } & Treatment & T0 (Second) & $\begin{array}{c}\mathrm{T} 1 \\
(\text { Second) }\end{array}$ & T2 (Second) & \multirow{2}{*}{$\Delta T 1-T 2 \pm S D$} \\
\cline { 3 - 5 } & & 40,76 & 65,24 & 73,2 & $-6,6 \pm 11,5$ \\
\cline { 3 - 4 } I & Control (-) & 51,28 & 59,64 & 8,4 & $51,24 \pm 16,73$ \\
II & Control(+) & 43,48 & 48,24 & 21,04 & $27,2 \pm 13,85$ \\
III & $\begin{array}{c}\text { Dose 5mg/20gram } \\
\text { weight Mice }\end{array}$ & & & &
\end{tabular}




\begin{tabular}{cccccr} 
IV & $\begin{array}{c}\text { Dose 10mg/20 gram } \\
\text { Weight Mice }\end{array}$ & 49,76 & 54,24 & 10,48 & $43,76 \pm 11,42$ \\
V & $\begin{array}{c}\text { Dose 20mg/20gram } \\
\text { weight mice }\end{array}$ & 41,68 & 51,24 & 14,28 & $36,96 \pm 6,31$ \\
\hline Informatian: \\
T0 $=$ Average escape latency trial for 5 days \\
T1 $=$ Average escape latency alcohol induction 10\% for 5 days \\
T2 $=$ Average escape latency gifing breadfruit leaf extract for 5 days
\end{tabular}

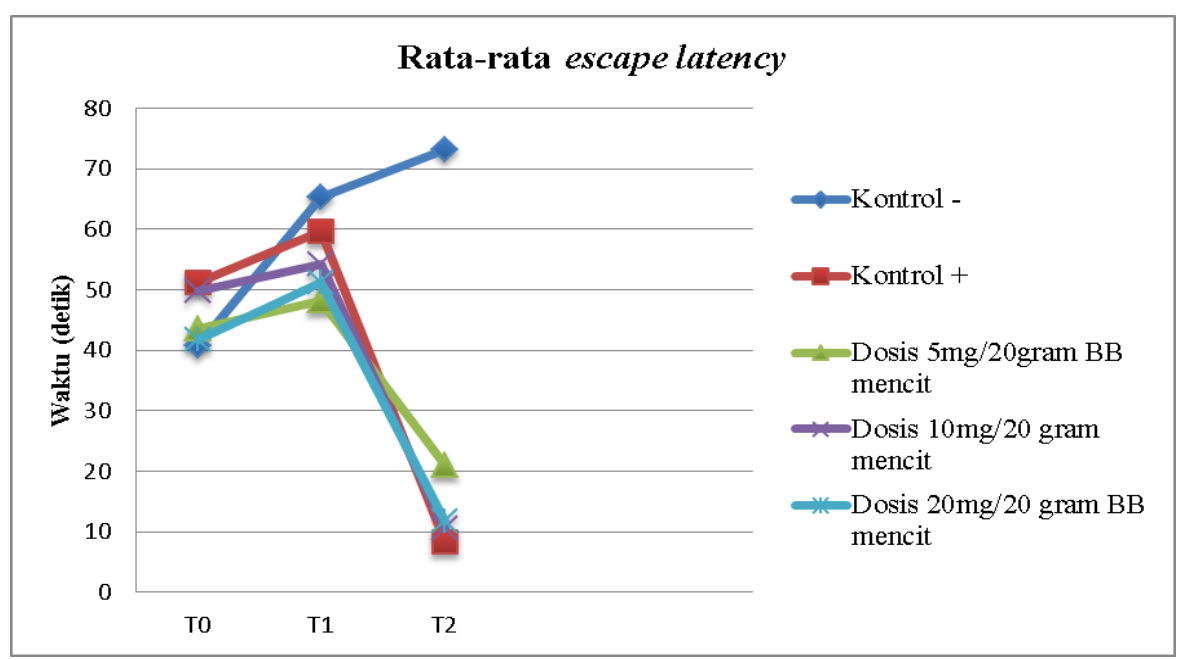

Figure 1. Graph of mean escape latency of test animals before and after treatment

Notes:

$\mathrm{T} 0=$ Average escape latency trial for 5 days

$\mathrm{T} 1=$ Average escape latency alcohol induction $10 \%$ for 5 days

$\mathrm{T} 2$ = Average escape latency gifing breadfruit leaf extract for 5 days

The graphic data above that after carrying out an acquisition trial, each treatment group experienced an increase in memory after being trained for 5 days. In the positive control, it can be seen that the escape latency is lower because the test animals are treated with pure dry extract of gingko biloba so that the effect can be seen from the data that gingko biloba is very good for improving memory in accordance with Ina's statement, 2017 giving gingko biloba to mice is more. fast because gingko biloba contains flavone compounds in this case flavonoids can protect cell membranes from ROS or reactive oxygen species. Flavonoids inhibit xanthine oxidase which uses oxygen molecules as electron acceptors to produce superoxide and hydrogen peroxide ions (Fermino et al. 2015).

The treatment given to the test animals showed an increase in latency time after $10 \%$ alcohol induction. in other words it does not improve memory. Dose $1=5 \mathrm{mg} / 20 \mathrm{gram}$ BW for mice 27.2 13.85, dose II $=10 \mathrm{mg} / 20 \mathrm{gram}$ BW for mice 27.213 .85 , dose III $=20 \mathrm{mg} / 20 \mathrm{gram}$ BW for mice 36.966 .31 and the positive control group 51, 24 16.73. From the three variations in the dosage of breadfruit leaf extract, the data showed that the second dose, 10mg / 20gram BW for mice, had only slightly different results from the positive control with a time difference of $10 \mathrm{mg} / 20 \mathrm{gram}$ BW for mice 43.7611 .42 and a positive control for gingko biloba of 51., 2416.73 the difference between the two groups is only around 7.52 seconds, so it can be said that the second dose of breadfruit leaf extract, which is $10 \mathrm{mg} / 20 \mathrm{gram}$ BW of mice, is an effective dose to improve memory in the test day.

The data that has been obtained is reanalyzed by statistical tests using one way ANOVA (one way ANOVA) because there are two variables that influence this study, namely the test group and the time of observation. In the results of statistical tests using the Sapiro Wilk Test, it has been stated that 
the data is distributed and the data is homogeneous, namely $\mathrm{p}(0.196)>(0.05)$. The results of the ANNOVA test showed the results of the significance shown from the test with a significant value of $p$ $(0.00)<(0.05)$ so that it can be concluded that each treatment group has a difference in the mean time of latency.

LSD test results showed a significant difference if the significance value (p) in each treatment was less than or equal to $(0.05)$ or $\mathrm{p}(\leqq 0.05)$. All showed significant differences with negative control $\mathrm{p}(0.000)$, while positive control with dose II 10mg / 20gram BW mice with $\mathrm{p}(0.495)$ then $\mathrm{p}>(0.05)$. So it can be stated that the ethanol extract of breadfruit leaves dose II $10 \mathrm{mg} / 20 \mathrm{gram}$ BW of mice is effective and influences spatial memory in male white mice.

\section{CONCLUSION}

1. The ethanol extract of breadfruit leaves affected the spatial memory of male white mice tested with morris water maze

2. The second dose of ethanol extract of breadfruit leaves $10 \mathrm{mg} / 20 \mathrm{gram}$ BW for mice and gingko biloba extract was not significantly different. So that the dose of $10 \mathrm{mg} / 20 \mathrm{gram}$ BW of mice has an effect on improving memory on the spatial memory of male white mice

\section{CONFLICTS OF INTEREST}

The author declares that they have no conflict of interest

\section{REFERENCES}

Ministry of Health. (2018). Hasil Utama Riskesdas Tentang Prevalensi Diabetes Mellitus di Indonesia. Jakarta

Hernández JA, López-Sánchez RC, Rendón-Ramírez A. (2016). Lipids and Oxidative Stress Associated with Ethanol-Induced Neurological Damage. Oxidative Medicine and Cellular Longevity.

Feng Y, Wang X. (2012). Antioxidant therapies for Alzheimer's disease. Oxidative Medicine and Cellular Longevity. Hindawi Publishing Corporation.

Riasari H., Sukrasno and Ruslan K. (2015). Metabolite Profile of Various Development Bread Fruit Leaves (Artocarpus altilis. Parkinson. Fosberg) and The Identification of Their Major Componens, International Journal of Pharmaceutical Sciences and Research.

Harborne JB. (1987). Metode fitokimia, peuntun cara modern menganalisis tumbuhan. Edition II. Padmawinata. Bandung: ITB. 